\title{
'Some dozen raupo whares, and a few tents': remembering raupo houses in colonial New Zealand
}

\author{
KRISTYN HARMAN
}

\begin{abstract}
This article traces the genealogy of colonial raupo buildings in New Zealand, and also charts their decline. This decline was in part attributable to the passage of the colony's earliest building legislation, 'an ordinance for imposing a tax upon raupo houses'. It draws on census data and settler reminiscences to demonstrate that collective memory of raupo houses became essential to settler New Zealand as a benchmark against which to measure colonial progress. It also shows how, in the early decades of the twentieth century, health concerns were mobilized as the official rationale for both the removal from raupo houses of those few Pākehā who continued to occupy them, and the wholesale destruction of many Māori-occupied raupo homes. By the 1930s, few New Zealanders continued to occupy raupo houses, and their extensive use by early colonists was conveniently forgotten. Remembering raupo houses in colonial New Zealand contributes to recent scholarship theorising the existence of a "middle ground' in the colony, at least until 1840 and potentially up to the 1860 s.
\end{abstract}

\section{Introduction}

As the British Empire celebrated Prince Edward's first birthday, during the night of 9 November 1842 a fire broke out in Wellington. It began in the thatched roof of Lloyd's bakehouse. The fire raced along the beachfront at Lambton Quay, incinerating 37 raupo houses and 20 wooden dwellings. Windy Point or Clay Hill (later known as Stewart Dawson's corner) provided a natural barrier that prevented the destruction of the bond stores and warehouses at Te Aro beach, although the total cost of the conflagration was high at $£ 16,000 .{ }^{1}$ Nevertheless, the New Zealand Company's principal engineer and surveyor Samuel Brees concluded that the fire 'proved beneficial in some respects, for the old raupo whares and toitoi roofs were replaced by substantial brick stores and buildings'. ${ }^{2}$ The November 1842 conflagration was the first major fire to afflict Wellington. Seventy years later, 'Old Identity' recalled the blaze, describing how numerous sailors rushed to the aid of the town folks, tearing down highly flammable houses while 'the thatch [was] carried bodily into the sea'. In reporting these reminiscences, the Hutt Valley Independent described how 'out of the ashes of the raupo thatch there sprang substantial brick and wooden stores and taverns with slate or shingle roofs'. Indeed, according to the newspaper, 'within two or three months this part of the beach was more thickly populated than ever before, and no vestige of the fire remained'. ${ }^{3}$

Raupo, or typha orientalis, is related to the bulrush and grows in New Zealand's wetlands around the shallow edges of lakes. ${ }^{4}$ Its water-repellent and insulating properties saw raupo used extensively as a building material by Māori. Some of the first Europeans who lived in New Zealand - onshore whalers and sealers - were provided with raupo whare as shelters by their indigenous extended families after having formed relationships with Māori women. These wooden-framed houses had walls insulated with bundles of dried raupo, thatched roofs, and large chimneys. ${ }^{5}$ As increasing numbers of colonists arrived, raupo remained a popular choice of building material for makeshift houses until the latter decades of the nineteenth century as discussed below. With just a few days' work a labouring man could cut enough raupo for a 'good-sized cottage', and raupo houses represented good value, costing settlers as little as $£ 7$ to $£ 8$ in the 1860 s for a three-bedroom home. ${ }^{6}$ 
In parts of New Zealand, timber was scarce. As Peter Shaw elaborated, this necessitated settlers engaging in forms of construction other than raupo huts. This study is therefore focussed more closely on the North Island than the South, as it is in the former that raupo houses dominated the early colonial built landscape and later memories. In the decade between 1858 (the first time houses were counted in a national census) and 1867, approximately $90 \%$ of raupo houses were located in the North Island. ${ }^{7}$ In the South Island, particularly in Canterbury, Otago, and Southland cob, wattle-and-daub, and turf houses were common. Some settlers in the latter two provinces emulated crofters' houses in Scotland, the place of origin for many immigrants. ${ }^{8}$

Particularly in the North Island, raupo was used not only for domestic dwellings but also for early churches, official buildings, commercial buildings, and some of the shelters used by the military during the New Zealand wars. As was the case in Wellington in 1842, raupo buildings proved highly susceptible to fire with many a structure being lost in conflagrations. Such was the heightened level of concern about the threat posed to adjoining properties in crowded towns that the first building legislation passed in the colony was an ordinance for imposing a tax on raupo houses, also discussed below. Those structures that avoided incineration disintegrated after about half a decade's use and were often seen by settlers as makeshifts to be replaced with timber, stone, or brick buildings as their finances improved. Therefore, raupo buildings did not become a permanent feature of colonial New Zealand's built environment and were, from the outset, a benchmark against which the material prosperity, development, and growth of the colony could be measured as they faded from the scene.

Gavin McLean explained how the majority of New Zealand colonists were not interested in conserving their landscape as cultural heritage. Instead, they were 'burners, builders, and boosters' who (as we have seen in relation to Wellington) were 'happy to celebrate the replacement of raupo whare with timber Gothic, or wooden buildings with masonry structures'. ${ }^{9}$ Despite settlers' apparently carefree attitude towards them, this article demonstrates how colonial raupo buildings eventually formed part of settler New Zealand's collective memory. As young arrivals from the early period of organised settlement grew old, the rush to record their memories of pioneering saw numerous anecdotes emerge about colonial childhoods spent in raupo huts. I argue that the collective memory of raupo houses became essential to settler New Zealand as a benchmark against which to measure colonial progress and civilization. As will be demonstrated, the progression from raupo to more permanent buildings and therefore from a community of makeshifts to a more civilized society was quantified in census data and qualified through reminiscences. Prior to engaging with pertinent census data, exploring memory in colonial settings, and considering relevant reminiscences, it is useful to investigate the genealogy of colonial raupo houses in New Zealand which, until now, has been subject only to cursory examination.

\section{A Genealogy of New Zealand's Colonial Raupo Houses}

Raupo, according to Dominion Museum ethnologist William Phillipps, was one of nine distinct categories of classic Māori houses. Early writers differed in their descriptions of such houses. However, most agreed these buildings exhibited a 'customary lack of height..., small doorways, and lack of furnishings'. ${ }^{10}$ In his 1890 s description of classic raupo houses, Reverend Herbert Williams described doorways no higher than four feet, and windows so high from the ground that a seated person could barely see out. He presumed the windows to have been positioned to provide protection in case of attack. ${ }^{11}$ Such observations about Māori houses had meaning only within a comparative framework where the yardstick was colonial expectations about housing design. They are nevertheless significant points, as it is these 
features of classic raupo structures that were modified to suit the early settlers for whom Māori built whare. $^{12}$

Along with sealers, on-shore whalers, timber getters, and traders, missionaries were among the first Europeans to settle in New Zealand. Initially, their needs for shelter were met through negotiations with local Māori. The resultant raupo structures became increasingly hybridised over time as European adaptations were incorporated into their design, often for practical rather than aesthetic purposes. Hybridity, according to James Belich, was one of the key defining characteristics of settler societies. It was useful for settlers to have had a 'hybrid metropolis' at the frontier that provided them with 'more than one suite of practices and techniques from which to select and adapt'. In considering hybridity, however, Belich focused on how various European cultures blended and borrowed from each other, rather than considering the influences of Māori practices and techniques on New Zealand settler society. ${ }^{13}$

The first raupo houses occupied by missionaries were simple, makeshift structures. In 1814, Māori built a raupo house at Rangihoua in the Bay of Islands to accommodate four families of Church Missionary Society (CMS) missionaries recruited to New Zealand by the then New South Wales-based Chaplain Samuel Marsden. These families were allocated separate rooms in the unusually large $60 \times 14$ foot structure, with partitions demarcating the allotted spaces. There were no floorboards, windows, or chimney. ${ }^{14}$ When CMS missionary (later Archdeacon) Henry Williams arrived at Paihia in 1823, he initially held services for Māori in his raupo house. In time, a raupo church was built and served the Christian community for several decades before being replaced in the mid-1850s by a lath and plaster church then, in 1874 , by a wooden church. ${ }^{15}$ A similar pattern of building followed the arrivals of missionaries of other denominations. For example, when the Methodist Reverend James Wallis reached Hokianga in 1834, he commissioned Māori at Whaingaroa to build a mission house. About 50 or 60 men were involved in the construction of the building over several weeks, with Wallis being allocated an 8' by 5' raupo hut in the interim. On completion of the house, attention turned to building a raupo church. The finished edifice was sufficiently large to seat a congregation of several hundred. ${ }^{16}$

In other parts of the North Island, Māori also constructed substantial raupo churches and missionary houses as the following examples from George Sisson Cooper's journal of an expedition from Auckland to Taranaki over the summer of 1849 to 1850 demonstrate. As part of Governor George Grey's entourage, Cooper visited a raupo church at Matamata. The seventy by forty foot building was 'supported by immense totara poles', with its altar, pulpit, and communion railings also being totara. The doors and windows were European in style. The entourage also visited a mission house formerly occupied by Archdeacon Brown. Built from raupo 'in the best native style', it was commodious, containing six rooms, and had Europeanstyle floorboards, doors, and windows. However, the house had 'a sadly desolate appearance', with all of the windows broken and the chimneys falling down. Warfare in the district had seen Brown relocate to Tauranga. ${ }^{17}$ Raupo missionary houses, as Bishop Selwyn's wife recalled, usually had 'windows down to the floors' to facilitate evacuation. This was an essential feature because 'if a raupo house caught fire, before you could count to twenty it would be flaming throughout'. Archdeacon Williams himself was burnt out of house and home not once, but twice, in his early years in New Zealand. ${ }^{18}$

Its ready availability also saw raupo used as a building material for makeshift housing used in official capacities. When Auckland superseded the Bay of Islands as New Zealand's capital, a 'bran (sic) new Government house from a London timberyard' was shipped to the colony on the barque Platina in 1840 as the Home Government thought the Governor of 'the new Great Britain of the South, should [not] run the risk of holding his first court in a raupo whare'. The New Zealand Herald elaborated that while Downing Street 'knew [not] what those 
two words meant... it had a vague idea that in a Cannibal Island some befitting shelter ought to be forthcoming for Her Majesty's Representative'. After the Platina foundered on a reef near Auckland, Apihai Te Kawau (the chief from Orakei from whom land for the new capital had been purchased) ensured all the officials were comfortably housed in raupo whare in Official Bay. Eventually, the prefabricated Government House from London was built, but came down faster than it went up as the single-storied wooden structure was destroyed by fire. ${ }^{19}$ Archival evidence demonstrates that Māori were also contracted by the colonial authorities to build raupo houses for official use. On 5 April 1850, Superintendent of Works Reader Wood informed the Colonial Secretary that he had authorised an advance of $£ 10$ with regard to the $£ 14$ promised to 'the native Te Kiri' to build a raupo hut for police stationed at Onehunga. ${ }^{20}$ It was intended as a replacement for the existing police house that was in 'a state with the rain pouring in all quarters' ${ }^{21}$ After inspecting the building, Commissioner of Armed Police Thomas Beckham was happy to endorse his Corporal's request and payment to Te Kiri was expedited. ${ }^{22}$

Some of Auckland's first public houses were built from raupo. ${ }^{23}$ One stood on a patch of dry ground near where a tidal creek ran along the western side of Queen Street. On the pub's roof stood a sign: 'help me through the world'. ${ }^{24}$ Publican Robert Field, a well-known colonial identity and cabinet maker, earned the nickname 'help-me-through-the-mud' as his patrons often had to be hauled out of the swampy ground outside his premises. ${ }^{25}$ The pub was 'a very curious edifice of raupo', a long building with two windows, a central door, and some internal partitioning. The dirt floor and raupo counter 'in a few days got saturated with slops, and became exceedingly filthy'. While Field's raupo pub has long since vanished back into the ground from which its building materials were originally harvested, the publican has nevertheless left his mark in Auckland as Field's Lane that runs between Shortland Street and Chancery Lane bears his name. ${ }^{26}$ Beyond Auckland, colonists also used raupo to construct hybridised buildings as settlement moved farther south. For example, the first Anglican Church at Lower Hutt was built 'after the style of a Maori whare and built of raupo'. Built on the Western bank of the Hutt River, the church was washed away in its entirety, together with the remains of the churchyard dead, when the Hutt River flooded in the early $1840 \mathrm{~s} .{ }^{27}$ The makeshift nature of early raupo churches ensured that none survived more than a handful of years, often just long enough for subscriptions to be taken up to build more permanent structures in their stead.

As the increasing numbers of colonists who arrived in New Zealand following its annexation by Britain failed to find familiar building materials, they contracted Māori to build raupo houses in return for cash payments or trade goods, or otherwise used canvas tents. In June 1842, Auckland harbour master Captain David Rough inspected some 'rapoo' houses at Mechanics' Bay that could be offered to immigrants. While 15 of the houses needed minor repairs, a further three were 'in a very bad state' and needed to be rebuilt. ${ }^{28}$ These were probably the raupo houses built in 1840 in exchange for trade goods by Ngati Whatua for the carpenters, sawyers, and masons who arrived from New South Wales. ${ }^{29}$ On 20 June 1842, John R Mallcott informed the Superintendent of Public Works that 'on application to the natives through W. Morant' he had found that they would make the necessary repairs for $£ 20 .{ }^{30}$ Issues arose over the contract, with the labourers not completing the job. Eventually Titipa wrote to the Governor to explain that while he had been working, he had had to fast. Titipa was not a local. He was from Otawao and, in the absence of an interim payment for his work, had to return there to access his food stores. ${ }^{31}$ Eventually, the Colonial Secretary was told to instruct the Colonial Treasurer to pay Titipa immediately for work which had by that time been carried out two years earlier. $^{32}$

Some wealthier colonists brought flat-packed houses out from England, but many comprised only prefabricated wooden frames. With few carpenters, little in the way of 
European building materials, and limited tools available in the new colony, these kit homes were often abandoned in favour of raupo whare. Colonists could anticipate getting up to half a decade's use out of a raupo whare, making this style of housing a good investment, even at a time when the construction price ranged as high as $£ 10$ to $£ 15$. If colonists prospered, they could modify their basic raupo houses in accordance with European tastes and practices by adding features such as internal partitions, imported doors, and verandahs. Calico window coverings could be replaced with glass, which (along with other European fixtures and fittings) could later be incorporated into the family's next home, often a wooden structure. ${ }^{33}$

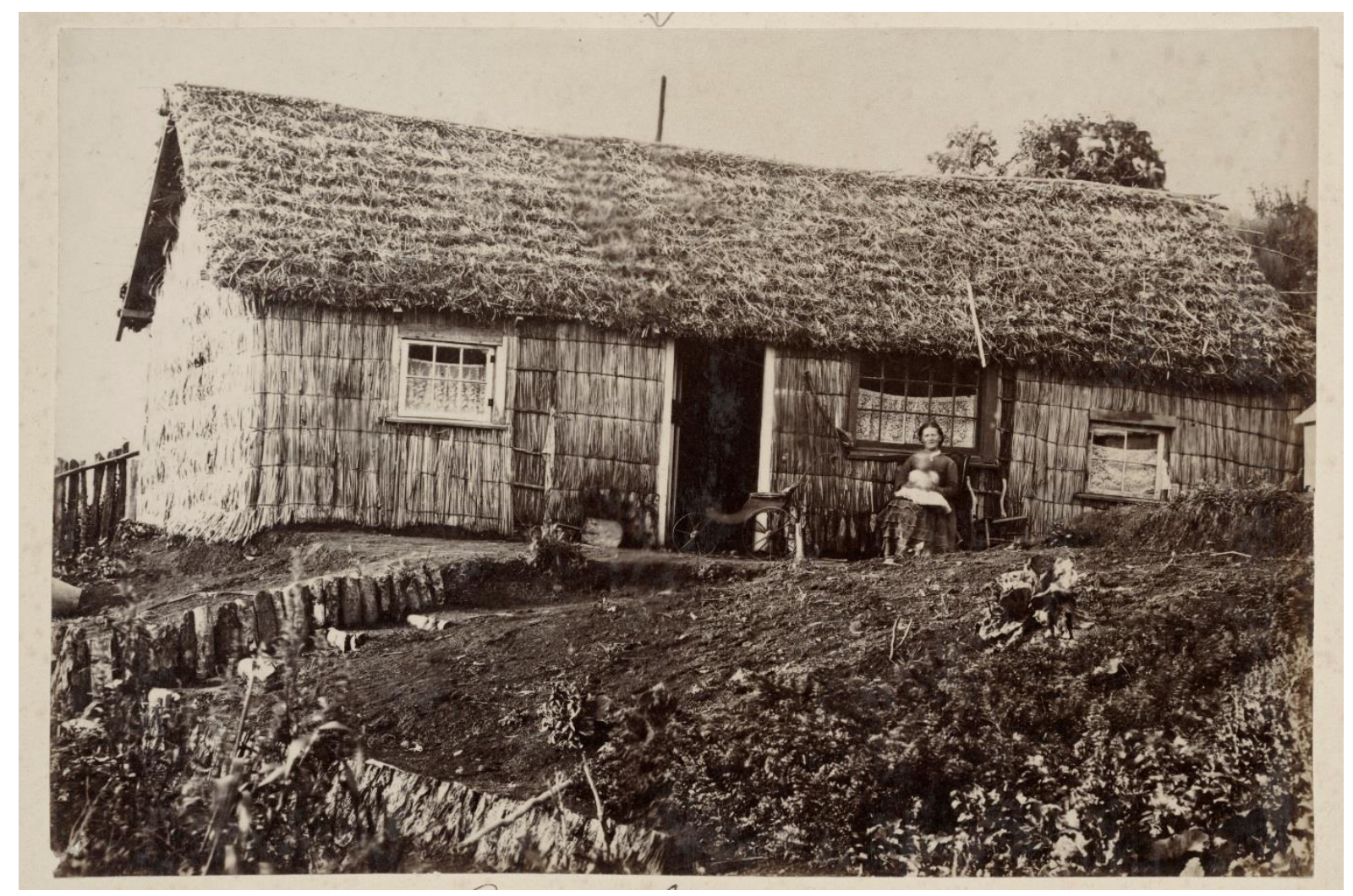

Raupo whare, Taranaki. Parihaka album 1. Ref: PA1-q-183-25-2. Alexander Turnbull Library, Wellington, New Zealand. http://natlib.govt.nz/records/22876402

New Zealand Company settlers were regularly housed in makeshift structures provided by Māori. For example, Donald Fraser, who arrived on the Blenheim in December 1840 as one of around 200 Company emigrants recruited from the Highlands, recalled being disembarked on Boxing Day and housed in raupo whares built by Māori at Taita. Each of the six or seven dwellings was 'partitioned off in about four rooms each with blue blankets for the doors'. Settler families were allocated one to two rooms, depending on their number. Fraser's family lived at Taita for about a year before moving to Wellington. ${ }^{34}$

\section{The Raupo Houses Ordinance}

As New Zealand's colonial towns became more established, the raupo houses within town boundaries came to be seen as posing an unacceptable risk to neighbouring properties. The seventeenth ordinance passed by the Legislative Council (in its second session in 1841/42) was 
an 'ordinance for imposing a tax upon raupo houses'. This ordinance was designed to discourage settlers from building with the highly flammable but readily available natural material. Each town's boundaries within which such houses could not be built were to be proclaimed, along with a date no later than 3 September 1842 after which colonists would be made to pay a $£ 20$ levy on their house if its materials of construction included raupo or similarly inflammable materials such as nikau, toetoe (toitoi), wiwi, kakaho, straw, or any other type of thatch. This levy was not a one-off penalty - it was to be paid annually to the Colonial Treasurer or District Treasurer by the homeowner. If any colonists built houses using banned building materials within the specified town boundaries after the ordinance came into force in their area, they would be levied $£ 100 .^{35}$

Part of Auckland was brought under the ordinance following a proclamation of the applicable town boundaries on 16 May 1842. On 28 January 1850, the raupo houses ordinance was proclaimed in relation to Dunedin and Port Chalmers. With regard to Wellington, Governor William Hobson had, with advice from his Legislative Council, issued a proclamation under the raupo houses ordinance on 30 March 1843, four months after the conflagration that destroyed many of Wellington's beachfront houses. ${ }^{36}$

A fortnight after the November 1842 fire, Wellington's Mayor George Hunter wrote to the Governor explaining it had begun in a raupo house. Hunter expressed his concern that many colonists whose possessions had been incinerated might be tempted to rebuild using the cheapest available materials. To prevent this, Hunter and his alderman wanted the provisions of the Raupo Ordinance extended to the Borough of Wellington and sought consent from the Secretary of State for the Colonies for the taxes gathered to remain with the Corporation of the Borough. ${ }^{37}$ Some colonists at Wellington reacted with 'surprise and alarm'. The $£ 20$ tax was considered 'enormous' and to have the potential to 'cause the ejection of thousands of the working classes from comfortable homes, constructed by their own labour, and would operate grievously upon many persons possessing capital'. ${ }^{38}$

The contentiousness between classes regarding the ordinance played out in public discourse for the remainder of 1842 and into 1843. Writing under the pen-name 'a working man', a Wellingtonian raised the issue that many who had brought capital to the colony failed to cultivate their land or to employ the working classes. Instead, they had become 'pettifogging shopkeepers'. The correspondent had 'not the least doubt that there is not a poor man in Wellington that would not gladly have a wooden, brick, or stone house if he could but afford it'. Many working class families simply could not afford to comply with the Government dictate to give up their 'Maori houses', a situation made worse through incurring a $£ 20$ fine should they fail to do so. He suggested that 'the owners of those splendid mansions' only had 'themselves to thank for all the ills that befall them' when they lost property through fires that commenced in nearby raupo houses. Had the wealthy developed their agricultural land, his argument ran, the poor would have had access to farm work and their raupo houses would have been built in rural areas. ${ }^{39}$

Following Hunter's death, Wellington's new mayor William Guyton and his aldermen petitioned the Governor in August 1843 to suspend 'the operation of the Raupo Ordinance in all parts of Wellington, except the beach, for six months' following the date on which it was to take effect (1 October 1843). The fire that caused such damage along the beachfront late the previous year was clearly still uppermost in people's minds. Yet Guyton and his council were concerned to protect those inhabitants who, owing to the state of trade and the unsettled question over land, were unable to build new, compliant houses by the proposed deadline. Police Magistrate Major Matthew Richmond conveyed the petition to the Auckland-based Colonial Secretary. ${ }^{40}$ However, on 27 September Wellingtonians were informed that the Attorney General, to who the matter had been referred, had found that it was not in his power 
to delay the introduction of the provisions of the ordinance, given that it had already been proclaimed in relation to the borough. ${ }^{41}$

Just one day after it took effect in Wellington, agent Charles Perry wrote on 2 October 1843 to Richmond requesting that the raupo ordinance be acted upon. The fire hazard posed by a clay and toitoi house next to the wooden Commercial Hotel on Lambton Quay alarmed Perry. Not only had he seen the hut catch fire after the guns were discharged at the Clay Hill Battery overhead, but the building was being used as a bakery. ${ }^{42}$ However, despite its now being law, Richmond had not been given any power to enforce the ordinance. Only the Colonial or District Treasurers had the authority to appoint a tax collector. ${ }^{43}$ This was resolved by the end of 1843 when Richmond himself was appointed by the Colonial Treasurer to collect the taxes payable within Wellington's specified town boundaries under the raupo houses ordinance. He was also vested with the discretion to determine which buildings' raupo roofs might pose a threat to their neighbours, and which might safely be ignored. ${ }^{44}$

\section{Building Raupo Houses in the Bush}

As raupo houses began to be replaced in New Zealand's colonial townscapes, and colonisation advanced in the bush, some settlers began to build their own bush houses using knowledge, materials, and technology that blended elements of Māori and Pākehā cultures. Detailed instructions directing intending settlers as to how to build houses in the bush were included in Joseph May's 1869 May's Guide to Farming in New Zealand, some of which were reprinted in colonial newspapers, and are worth reproducing at some length because of the significant insights they provide. May recommended raupo, nikau, or toitoi as cladding due to the ease of procuring and building with these plant fibres, and also because of the insulation provided. Begin building, he wrote, by cutting eight-foot long posts of hard wood at least six inches in diameter and levelling these at the ends to support the wall plate. Mark out the floor area of the house according to the size of the family. Twelve feet by twenty feet was considered sufficient for two 'good-sized' rooms. Then dig two-foot deep holes for the corner poles. Once these poles were square, they could be used as a guide to position posts two-feet apart around the external structure, leaving gaps for the doorway, windows, and chimney. The ridge pole, with a diameter of two to three inches, ought to rest on poles at least 14 feet long to ensure a decent pitch for the roof. Battens followed, nailed to the walls and roof at ten inches apart. The house was then ready for its raupo, nikau, or toitoi cladding to be tied to the framework using flax and for its chimney to be built. May suggested that 'by inquiring of some old residents', new chums could soon learn the required method of tying bundles of raupo to the framework. However, another unnamed writer whose advice was reprinted in the same newspaper claimed that 'the approved mode of tying is the one practised by the Maori' which 'must be seen to be understood'. This implies a transfer of knowledge from Māori to Pākehā and from old settler to new. Either way, raupo houses represented good value for settlers, costing (according to May, writing in the late 1860s) around $£ 7$ to $£ 8$ for a three-bedroom home (excluding the floor) that ought to last for about half a decade. Owners, however, had to remain vigilant to ensure that their raupo houses did not, within a few months of being built, become infested with rats and mice. ${ }^{45}$ 


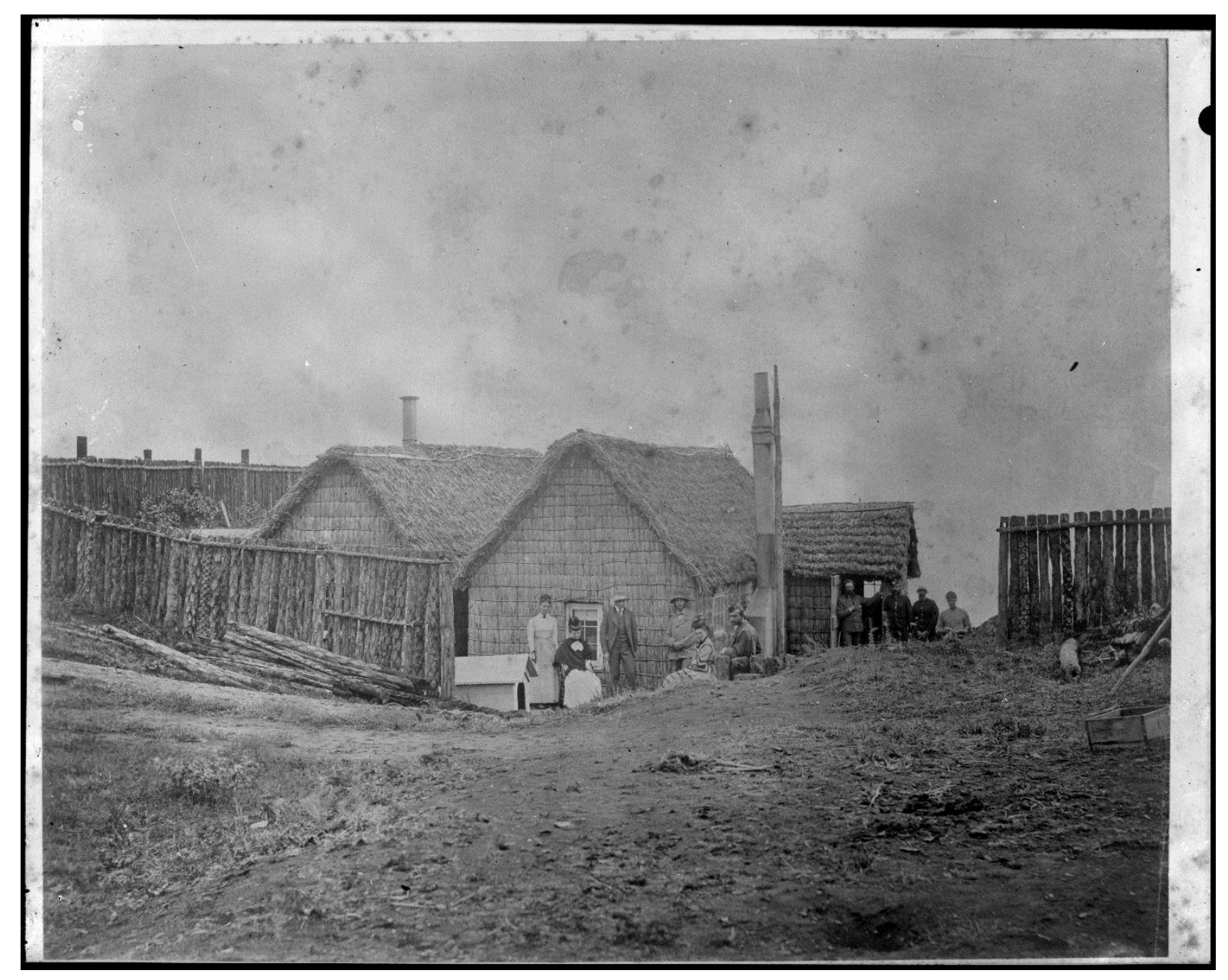

Captain William Bazire Messenger's raupo house at Pukearuhe, New Plymouth. Messenger was a veteran of the New Zealand Wars, having been commissioned into the Taranaki militia in 1860. He later served in the Armed Constabulary Force.

House at Pukearuhe. Goodman, S C (Mr), fl 1975: Photograph albums and loose prints. Ref: PA1-q-092-08. Alexander Turnbull Library, Wellington, New Zealand. http://natlib.govt.nz/records/23047649

During the New Zealand wars, some use was made of raupo for sheltering the military. In May 1864 , for example, a newspaper correspondent travelling with the $65^{\text {th }}$ and $40^{\text {th }}$ regiments near Te Awamutu in the Waikato described soldiers as having to 'go a great distance' to procure raupo for their huts. Raupo was, however, very difficult to obtain as winter approached and the swamps had flooded. Given the urgency of providing adequate shelter for the men, the correspondent advocated building barracks similar to a recently-constructed wooden stable with a corrugated iron roof. ${ }^{46}$ Some militia, such as those of the $1^{\text {st }}$ Waikato Regiment at Maketu, continued to be housed under canvas. The discomfort led to their investing in raupo huts at a premium price of $£ 15$ per building. In May 1865, fire spread rapidly through the raupo encampment. With the nearest water supply being a quarter of a mile away, there was little hope of slowing its progress. A report at the time condemned the Government for having provided tents rather than huts, thereby creating a situation in which men had resorted to the use of raupo. The total fire damage was estimated at $£ 2,000$, the brunt of which was borne by the families whose belongings were incinerated within their raupo homes. ${ }^{47}$ 


\section{Remembering Raupo Houses as a Benchmark for Progress}

As temporal and physical processes saw the materiality of colonial raupo houses fade from New Zealand's urban and bush environs, the process of their replacement with more substantial buildings made from wood, stone, or brick was quantified in the census. Raupo houses, as they diminished as a percentage of total housing, became a benchmark against which colonial society measured its progress. 'National memory', according to James Fentress and Chris Wickham, has, 'since the arrival of capitalism in each country' been borne by 'the upper middle classes and the intelligentsia, who have inherited the mantle from the aristocracies, lawyers and clergy of previous epochs'. They described this form of memory as having less to do with what they have termed the 'actual "pastness" of the past' and more to do with lending 'an objective veneer to the preoccupations and self-legitimizations of national bourgeoisies'. Some of the examples they drew on to illustrate this point include the significance of the Industrial Revolution and the nation state to the English, and the Renaissance and Risorgimento to the Italians, all of which were 'major building blocks of national self- identity'. ${ }^{48}$ I am suggesting that within the New Zealand context, charting the movement away from colonial raupo houses functioned similarly as a signifier of nascent Pākehā identity and the development of that identity through associated discourses of progress and civilization. In a similar vein, and touched on briefly below, the increasing insistence that Māori give up raupo housing for wooden structures (while predicated on concerns for health) also fits within a narrative of a colony that imagined itself to be progressing towards a more civilized state.

While census data enumerating a shift in the use of housing materials underpinned discourses of progress from the late $1850 \mathrm{~s}$ until the 1870s, by the closing decades of the nineteenth century the focus shifted to individual memories of early pioneers as evidence for progressive change. Such personal memories, according to Fentress and Wickham, have 'their own specific grammars' and must be analysed both as narratives and in terms of the functions that they serve for the societal group from within which they are generated. Once articulated, in this case through being published in colonial newspapers, personal memories became 'shared memories' that take form within a framework devised by the social group to whom they then belonged. ${ }^{49}$ The development of a shared view of the past, partly through using raupo houses as a yardstick against which to measure progress, saw Pākehā social identity evolve in colonial New Zealand.

\section{Census Data, Raupo Houses, and Narratives of Progress}

The first national census was conducted in 1851. While the New Zealand census was used to gather data about various aspects of life in the colony, census taking was far from being a neutral process. Instead, census questions and categories were informed by the values of those who designed and authorised it. Writing in the context of the impact on Ngāi Tahu, Wanhalla has shown how colonial authorities used evidence from the census 'to define a population, [however] the census statistics that emerged did not reflect the everyday reality of the people concerned'. Census data, as Wanhalla demonstrated, was used as evidence of the extent of cultural and physical assimilation of Māori. ${ }^{50}$ At the same time, it was also being used to support notions of European progress as will be explored below, drawing on examples from a range of colonial newspapers. First, though, a brief discussion of the relevant census data is warranted.

The earliest count of houses as part of census-taking in the colony did not occur until 1858, a time at which the construction of raupo dwellings was increasing when taken as a raw number (presumably to meet the short-term housing needs of colonists arriving in increasing numbers), but declining markedly when measured as a percentage of total housing. The following table summarises statistical data from 1858 to 1867 , indicating the prevalence of 
raupo houses and their distribution by province. ${ }^{51}$ Figures do not include houses occupied by the military and their families, the colonial defence force, or by Māori as these were not counted in the census. The number of raupo houses in the Wellington province is comparatively low, a situation brought about through the devastating fire of 1842 and the introduction of fines under the raupo houses ordinance the following year, which saw Wellingtonians begin to prefer wood as a building material (stones and bricks being less popular in the earthquake-prone province). Provinces are grouped according to the categories delineated in the 1858 census (these groupings changed from census to census):

\begin{tabular}{|l|l|l|l|l|l|l|l|l|}
\hline & $\mathbf{1 8 5 8}$ & $\mathbf{1 8 6 1}$ & $\mathbf{1 8 6 4}$ & \multicolumn{1}{l|}{$\mathbf{1 8 6 7}$} \\
\hline Province & Raupo & Total & Raupo & Total & Raupo & Total & Raupo & Total \\
\hline Auckland & 353 & 4117 & 430 & 6063 & 437 & 7823 & $* *$ & 10509 \\
\hline Taranaki & 22 & 680 & 10 & 438 & 16 & 748 & 49 & 1057 \\
\hline Wellington & 53 & 2799 & 59 & 3081 & 40 & 3006 & 37 & 7354 \\
\hline Hawke's Bay & 89 & 451 & 54 & 579 & 39 & 679 & 84 & 1075 \\
\hline $\begin{array}{l}\text { Nelson and } \\
\text { Marlborough }\end{array}$ & 16 & 1756 & 20 & 2385 & 3 & 3851 & 9 & 7782 \\
\hline $\begin{array}{l}\text { Canterbury } \\
\text { Otago and } \\
\text { Southland }\end{array}$ & 34 & 1741 & 56 & 3237 & 19 & 6540 & 2 & 12857 \\
\hline
\end{tabular}

* Raupo houses were included within the 'Other Materials' category in 1858. These figures were calculated using a ratio derived from the proportion of raupo houses to a combined total of houses built from 'Raupo' and 'Other Materials' in the 1861 census.

** The total number of raupo houses in the Province of Auckland was not listed in the 1867 census.

The census data tabulated above is a minima, in part due to the exclusions above, but also owing to some problems with the census itself. As a newspaper reported in response to the 1864 census, it was 'well known that census papers have not been left at very many houses, and at others where they have been they have not been filled up, or have not been called for'. The probability of an undercount was exacerbated through a recent influx of settlers into Auckland, leading the Daily Southern Cross to speculate that the town's population (and, therefore, their housing) was much higher than census returns showed. ${ }^{52}$ While the colony celebrated steady increases in population and housing throughout the $1860 \mathrm{~s}$, the numbers of dwellings were skewed by an upsurge in the use of tents in the goldfield regions, with 6742 tents being counted as dwellings in 1864, and 4595 in $1867 .{ }^{53}$ Nevertheless, some interesting trends are illustrated by the following graphs. The vast majority of raupo housing was located in the North Island. During the 1860s, raupo housing as a proportion of total housing (which included buildings constructed from brick or stone, wood, or other materials) fell markedly, although results from 1867 are skewed by the absence of a figure for raupo housing in the 
Province of Auckland, an area historically associated with the highest number of raupo dwellings.

\section{Number of raupo houses}

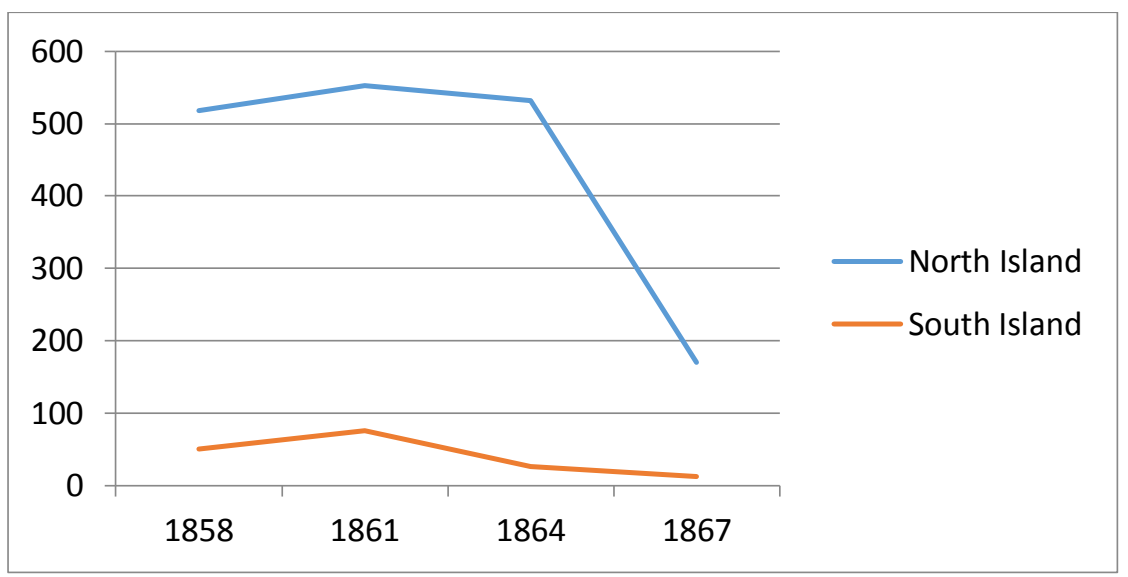

\section{Raupo houses as a percentage of total housing}

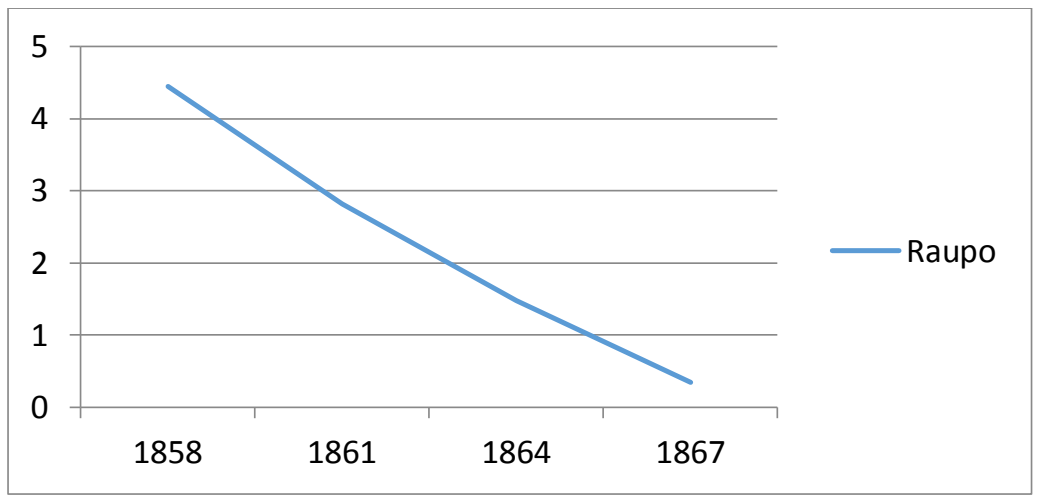

Evidence from the 1858 census, which had been taken on Christmas Eve, was later used in newspapers such as the Wellington Independent 'for the sake of clearly showing the progress made' in each of New Zealand's provinces. The first set of figures tabulated in the newspaper's columns showed the numbers of dwellings per province and the types of materials from which they were constructed. While these figures showed that wooden houses now outnumbered those built from raupo (the latter being included in the category 'other materials'), the Wellington Independent was bound to observe that houses had not been counted in the census prior to 1858. Nevertheless, housing data (along with data showing increases in population, land under cultivation, and livestock numbers) formed part of the newspaper's evidence of 'reason for congratulation that such marked progress has taken place'. ${ }^{54}$

In reporting on the 1861 census data, the Nelson Examiner and New Zealand Chronicle noted how 'the facts that these returns disclose show most conclusively the satisfactory progress which all the provinces of the colony are making, excepting unfortunate Taranaki, in population and wealth'. The first category of census data mentioned by the newspaper was housing, followed by European population numbers. Despite the 1861 census 
being the first for which comparative data was available in relation to the number of houses in each province and the materials from which they were built, this level of detail was not provided to readers. ${ }^{55}$ Other newspapers, such as the Lyttelton Times, engaged with the census data on housing in more detail. Its readers were provided with comparative figures for each province, showing the total numbers of houses counted, and the type of materials from which they were built. This information was valuable in providing information 'as to the social status of each province'. The figures demonstrated a move away from housing built from raupo and other materials (taken as a percentage of total housing) to those that were wooden or built from stone or brick. The exception to this was Otago where the gold rush saw 4,423 of the total 6,136 houses enumerated 'being composed of other materials such as sod huts, tents, \&c., speaking strongly of the migratory habits of her population'. Despite this, and the impacts of war on Taranaki, the Lyttelton Times concluded that the census data provided just cause for congratulations throughout the colony on the progress being made by its (European) inhabitants. ${ }^{56}$

In introducing tables of data compiled from the 1864 census, the Nelson Examiner and New Zealand Chronicle argued that statistics had, since the middle of the eighteenth century, become 'a most important study' that revealed 'nothing less than an investigation and exposition of the real condition of states and nations'. According to the newspaper, 'statistics, in their most comprehensive form ... [show] the degree of civilization attained by' a country's inhabitants. ${ }^{57}$ By 1867 , some newspapers were engaging in more comparative analyses of census data with the Southland Times, for example, providing illustrative figures showing how housing in the colony totalled 54,000 against the lesser figure of 37,996 three years earlier. Further details were provided to illustrate the breakdown of housing by type of building materials, showing that the vast majority of houses were constructed from wood. Those built from raupo had fallen to just 868 , or less than $2 \%$ of dwellings. ${ }^{58}$ Such figures, to European minds in the latter decades of the nineteenth century, indicated progress, prosperity, and the evolution of a civilized society.

\section{Settler Memories as Measures of Progress}

In the early decades of the twentieth century, as the few first settlers who remained diminished in number, reminiscences were published about their early years in the colony. Such accounts encapsulated what was being touted at the time as the 'true spirit of the pioneer'. Settlers were said to have taken hardships in their stride, and first basic homes in New Zealand were often romanticised in ways that were consistent with the 'image of New Zealand... as an ideal society for European settlers' with 'the characteristics of... Arcadia'. ${ }^{59}$ For example, in 1909 'Devonia' recalled living in a 'pretty, fresh, clean and artistic' raupo house during her own childhood. Upright posts provided supports between which the 'shining yellow stems' of the raupo, 'cane like in appearance', was tightly woven. Partitions within the family home were also constructed from raupo, with the end result, according to 'Devonia', being a 'smooth and shining ribbed yellow lining' which was 'beautifully clean and sweet scented and not by any means to be despised'. In a similar vein, the same writer remembered how Taranaki couple Mr and Mrs Chilton had built themselves a raupo house. Raupo was used not only to complete the structure, but also for its soft furnishings. Before using it in bedding, the fluffy raupo was baked in an oven after having been sewn into calico bags to avoid it becoming 'unpleasant'. Māori women wove flax mats that were used on the floors of the Chilton's and others' huts. ${ }^{6}$

Not all early settlers' reminiscences conformed to a shared notion of Arcadia as examples drawn from different provinces illustrate. Looking back, early settlers from Auckland remembered a time when the town consisted of a few tents and raupo huts beside Waitemata harbour, mostly populated by a small group of government officials shipped over from New 
South Wales to form the nucleus of the new colony's civil service. ${ }^{61}$ 'An Early Settler' reminisced about having been 'led to believe that Auckland was a town' only to be 'greatly depressed' on 'beholding a few hills covered with brown fern and manuka scrub; some dozen raupo whares, and a few tents' ${ }^{62}$ This settler was not alone in their disappointment. Similar sentiments were experienced in different parts of New Zealand as early arrivals found that the scenes that greeted them were far from the rosy pictures painted to convince them of the wisdom of packing up their families and few belongings to move to the other side of the world. While not Arcadian in trope, such memories nevertheless fit within an overarching European framework within which Pākehā identity was seen as being forged through the shared experiences of moving from an economy of makeshifts (symbolised by the use of colonial raupo houses) and its associated hardships, to one of civilisation wrought through progress effected through sustained effort.

This grand narrative was also sustained through memories of raupo houses used by colonists as shelters of last resort, with Māori involvement in their construction often downplayed. When in 1900 Christchurch residents were reminiscing about the first settlers' houses to have been built, Dugald MacFarlane wrote to the Star. Vividly recalling his first visit to Christchurch with his father, MacFarlane remembered how they had walked up a bridle track to the top of the hill, joined a Māori track that crossed the Heathcote below Wilson's Bridge, and stopped the night in a raupo whare built for a Mr Williams, or in a neighbouring whare. MacFarlane explained that 'there were a row of these whares put up by Maoris for $£ 10$ each for different settlers'. While he could not specify the exact site, he remembered it was in the vicinity of the hospital. ${ }^{63}$ Similarly, in Taranaki, "raupo whares had to be resorted to at the outset' by the settlers who were predominantly from Devon and Cornwall in England. According to a newspaper report published in 1924, whare were replaced by wooden houses with shingled roofs as soon as the settlers had access to pit-sawed timber. The idea of progress and civilization being signified by a shift away from raupo housing is clearly evident in this early twentieth-century reportage. ${ }^{64}$

Widespread use of raupo housing, particularly by early settlers in the North Island, was also, as we have seen, accompanied by a range of cautionary tales often associated with such structures being rapidly destroyed by fire or carried away in flood waters. Wind, too, posed a problem to the early European occupants of these dwellings. Speaking at a church in Pitt Street, Auckland, in 1889, Reverend Ward was sharing his memories of the Taranaki War which included a catastrophic service presided over by his father in a small raupo whare. Just as Ward senior was delivering a homily on 'the wind bloweth where it listeth', a sudden gust caused part of the structure to collapse on the congregation who promptly fled before the collection could be taken up. ${ }^{65}$ It was almost as if nature conspired against anything more than the most temporary usage of raupo houses by the colonists whose societal evolution came to be synonymous with the evolution of their housing design from hybridised raupo whare, to wooden houses, then to buildings constructed from brick or stone.

\section{Condemning Raupo Houses}

Despite their prevalence as the mainstay of the built landscape across the North Island, colonial raupo houses all but faded from memory as the nineteenth century gave way to the twentieth. In the early twentieth century, those few Pākehā who continued to live in raupo huts became objects of colonial curiosity. In 1906 Dr Gordon MacDonald spoke at length with fellow Scot, Donald Sutherland, who was known as 'the Hermit of Milford Sound'. Sutherland's early years were characterised by roving, and included fighting in Italy, travelling to the New Zealand goldfields, then fighting in the New Zealand Wars. After a second stint at the goldfields, this 
time at Hokitika, Sutherland had renounced money and society to live in relative isolation at Milford Sound. He declared:

What's the good of money? ... You worry and fret, and lie, and kill yourself to hoard a little gold, and when it's all done, the Captain shouts, 'Strike sails, boys!' and down you go to Davy Jones' locker without more ado. No, no, I can live on the smell of the north wind, and a raupo hut is as warm as a palace. ${ }^{66}$

By the 1920s, the habits of some raupo house-dwelling recluses attracted opprobrium from their contemporaries. Patrick Carr, who had made his home in a 'lean-to hut fashioned from poles and raupo, not worthy of being dignified by the name of "whare"" in the Waitemata Borough of Auckland, had no desire to move, despite the police having tried to persuade him to enter a retirement home. During several court appearances, Carr produced 'a very grimy expanse of tracing paper' in an unsuccessful bid to convince the judiciary that he had squatting rights. Ultimately, following a violent altercation with a Borough Council Inspector, Carr 'left Swanson, Auckland, and the open life he loved for the mental hospital at Avondale'. Society would no longer tolerate what was seen as Carr's idiosyncratic behaviour. ${ }^{67}$

Concerns about health also dictated official attitudes and actions towards those Māori who continued to inhabit raupo whare. Part of the 'civilizing mission' had involved trying to persuade Māori to modify their housing to comply more closely with European norms. For example, in 1846, Rotorua-based missionary Thomas Chapman reported a small measure of success after years of effort in that he had persuaded his Māori head teacher to incorporate internal partitions into the man's new whare. ${ }^{68}$ However, not all Māori were interested in adapting their housing to conform more closely to European cultural norms. This led to raupo housing being singled out as a principal cause of Māori ill health and population decline, as was the case when an epidemic involving cellular inflammation devastated the population at Parihaka in 1884. On this occasion, the Native Minister distributed a circular reiterating advice he had received from Dr O'Carroll in which the doctor, who had been sent to treat the ill, attributed the disease to 'the filthy state of the settlement'. He condemned raupo housing with its lack of adequate ventilation and incapacity to 'be cleaned like wooden houses'. O'Carroll recommended that all raupo whare occupied by those who had been sick be pulled down. ${ }^{69}$ While environmental factors could have aided the spread of infection, the cellulitis erysipelas with which the sick were afflicted was caused by streptococcus bacteria and exacerbated by stress. ${ }^{70}$ The tremendous stress under which the colonists had put the people of Parihaka throughout the preceding two decades was likely to have exacerbated their condition, and contributed to the decline in their physical living conditions.

As the nineteenth century gave way to the twentieth, measures were put in place to compel Māori to adopt European-style housing and to improve sanitation. Health Department Native Medical Officer Dr Maui Pomare attributed the impetus behind the reform movement to the passage of the Maori Village Counties Act 1900. Under the auspices of this legislation, Pomare and other inspectors visited Māori villages and made recommendations for improvements. He reported having 'condemned hundreds of whares'. Living conditions for Māori on the east coast of the North Island were considered to have been substantially improved by the erection of over 120 European-style houses over the preceding year to replace raupo whare with their lack of ventilation, internal partitions, or floorboards. In line with trends emerging in the United States of America and parts of Australia in relation to reserves held communally by indigenous people, Pomare also advocated that Māori land be converted to individual title. ${ }^{71}$ 
Pomare took up his position with the Health Department in 1900, and was joined five years later by Te Rangi Hiroa who worked as his assistant. One of their key aims was to bring about an improvement in Māori housing. Pomare and Hiroa 'condemned numerous badly situated and otherwise substandard dwellings, and often had them burned or demolished in their presence'. Some Māori continued to build raupo whare, but increasingly Māori villages were predominantly or wholly comprised of wooden houses built to conform with European expectations. Not everyone found this transition to their liking, with complaints being made that the wooden houses were not as well insulated and were less picturesque than raupo whare. $^{72}$

By the 1930s, the Māori transition from raupo whare to European-style housing was virtually complete. In a public lecture evaluating Māori responses to coming into contact with civilisation, Bishop of Waiapu Herbert Williams (grandson of Bishop William Williams, and son of Bishop Leonard Williams) explained how the raupo whare 'had died hard'. It had, he said, 'offered a homeliness and warmth' to Māori. However, most had now moved away from their centralised kainga to take up their own land and, in the process, had adopted 'the European form of household'. ${ }^{73}$ Williams may have been satisfied that he had had the foresight to record details of Māori beliefs and practices surrounding the construction of raupo whare while they were still the predominant form of indigenous housing in the late nineteenth century.

\section{Conclusion}

In the early years of colonial contact in New Zealand the prolific use of raupo dwellings (particularly in the North Island) by early colonists stood as testament to, and symbol of, encounter and exchange. From the early decades of the nineteenth century, when Māori began to construct raupo buildings for sealers, onshore whalers, and missionaries, the first colonists were largely dependent on Māori for their housing needs. Following the signing of the Treaty of Waitangi in 1840, and the resultant influx of colonists (including into the New Zealand Company settlements), raupo structures were a common sight in the colony's growing towns. Such buildings were popular with those wanting to establish themselves quickly whether it be for business (as in the case of the first public houses in New Zealand) or government (a number of the colony's first structures of governance being built by Māori from raupo) as they were relatively inexpensive to procure and did not take long to construct. Colonists requiring makeshift domestic dwellings also often turned to raupo huts to meet their needs.

Over time, cultural contact informed subtle changes in design to raupo buildings used by Māori, as well as inflecting European housing in early colonial New Zealand. The colonial raupo structures were not identical in design to those used by Māori prior to cross-cultural contact. Māori-occupied raupo dwellings changed under the influence of settler colonial mores, and the raupo buildings occupied by the colonists become increasingly hybridised structures. Built from natural resources found in the New Zealand bush, and using construction methods developed by Māori, some raupo houses occupied by colonists included distinctly European features such as wooden floorboards, curtains, and glass window panes, while churches built from raupo were fitted out with European fixtures such as altars, pulpits, and communion railings.

As the 1840s progressed, the popularity of raupo buildings within town boundaries began to decline following a number of fires that highlighted the risks to the inhabitants of raupo premises and the persons and property of adjacent dwellings due to the incendiary nature of this building material. Regulations saw zones introduced in major towns such as Auckland and Wellington, and, later, at Port Chalmers and Dunedin in which heavy and ongoing fines provided a strong disincentive to using raupo as a building material. However, raupo buildings continued to be a distinctive feature of bush-dwelling colonists' allotments, initially being used 
as houses but often being repurposed as outbuildings as the settlers' situations improved and they built slab huts, or houses from other materials such as stone or brick. Over the same period, Pākehā reliance on Māori expertise diminished so that by the 1860s advice was being published in colonial newspapers and in books to intending and newly-arrived colonists, informing them of the step-by-step procedures involved in constructing their own raupo houses.

By the time that housing was being enumerated in the census, in the late $1850 \mathrm{~s}$, raupo houses were continuing to grow in terms of their raw number as the numbers of newcomers into the colony rose, but were steadily declining as a percentage of overall housing. Colonists were turning to alternate building materials such as wood, brick, or stone. Along with the rise in European population numbers across most of the provinces, and increases in stock, flocks, and land under cultivation, the shift away from makeshift housing in the form of raupo huts or tents was taken as a measure of increasing prosperity and, therefore, of the advancing state of civilization in the growing colony. Indeed, raupo houses as a percentage of total housing occupied by the colonists followed a steady downwards curve when charted across the 1860s. Such was the decline in their use that by the end of the nineteenth century any Pākehā who chose to continue to occupy a raupo house through choice became something of a curiosity.

After the turn of the century, attitudes shifted. A dichotomy emerged whereby on the one hand, as old settlers were fading from the scene, the rush was on to record their memories of life in the early days of the colony while on the other hand some of those who continued to live lives consistent with those earlier times were pathologized and institutionalized. Raupo houses were romanticised as the cosy flower-bedecked initial homes of those who arrived in the colony in the $1840 \mathrm{~s}$, but were no longer considered fit abodes for Pākehā occupants in the twentieth century. Health concerns were cited as the rationale behind forcibly removing Pākehā from raupo housing in the early decades of the twentieth century, and also for destroying numerous Māori homes built from this traditional material.

Having Māori make the transition from raupo to weatherboard homes was celebrated as a measure of the colonists' success in civilizing the nation's indigenous people, just as similar transitions from raupo to wooden and then to stone or brick dwellings had been lauded as symbolising the development of the colony in the nineteenth century. Despite their prevalence in the early decades of the colony, and their use as a yardstick against which to measure European (and, later, Māori) 'progress' in New Zealand, over time the extensive use of raupo houses by the first European settlers was conveniently forgotten. Remembering colonial raupo houses reinscribes into New Zealand's historic record initial Pākehā reliance on Māori for the provision of housing, and a later post-1850 period during which some Pākehā appropriated Māori building technologies and materials to build their own bush huts. Recognizing this contributes towards a nascent body of scholarship theorising the existence of a 'middle ground' in early colonial New Zealand which was characterised by interdependence between Māori and Pākehā. It was more than coincidental that by the 1860 s, when several major conflicts in the New Zealand Wars destroyed any remaining vestiges of the middle ground, the colonial use of raupo houses was in decline. ${ }^{74}$ 
1"Saturday, 12 November 1842," New Zealand Gazette and Wellington Spectator, 12 November 1842, 2; "Previous Big Fires in Wellington," Wanganui Chronicle, 25 October 1906, 2.

${ }^{2}$ Ibid.

3 "Peeps into the Past, the First Big Fire, Wellington." Hutt Valley Independent, 15 June 1912, 4.

${ }^{4}$ Nigel Isaacs, "Going back in time: raupo houses" BUILD, 90 (2005): 103.

${ }^{5}$ Peter Shaw, A History of New Zealand Architecture (Wellington: Hodder, Moa, Beckett, 2003), 14.

6"How to build a house in the bush." Daily Southern Cross, 13 September 1869, 7.

7 "No. 6. Comparative table showing the numbers and descriptions of houses or buildings in New Zealand (exclusive of the Chatham Islands) in December 1858, and December 1861, respectively, with the increase or decrease shown by the census of 1861, and the proportion of the population to the houses at the respective periods," Statistics New Zealand, accessed 25 October 2013, http://www3.stats.govt.nz/historic_publications/1861-statistics-nz/1861-statistics-nz.html; "Table 7.1. Comparative table showing the numbers and descriptions of houses in New Zealand, in December 1861 and December 1864, respectively, with the increase or decrease shown by the census of 1864, and the proportion of the population to the houses at the respective periods," Statistics New Zealand, accessed 25 October 2013, http://www3.stats.govt.nz/historic_publications/1864-statistics-NZ/1864-statisticsNZ.html; "Table showing the numbers and descriptions of houses (inhabited), and the domestic condition of the population (exclusive of aboriginal native), in New Zealand, as ascertained by a census taken in December, 1867," Statistics New Zealand, accessed 25 October 2013, http://www3.stats.govt.nz/historic publications/1867-statistics-nz/1867-statistics-nz.html.

${ }^{8}$ Shaw, 15.

${ }^{9}$ Gavin McLean, "Where Sheep May Not Safely Graze: A Brief History of New Zealand's Heritage Movement 1890-2000," in Common Ground: Heritage and Public Places in New Zealand, ed. Alexander Trapeznik (Dunedin: Otago University Press, 2000), 25.

${ }^{10}$ William J. Phillipps, Maori Houses and Food Stores (Wellington: Dominion Museum, 1952), 15, 78 80 .

${ }^{11}$ H. W. Williams, "The Maori Whare: Notes on the Construction of a Maori House," The Journal of the Polynesian Society 5, no.19 (1896), 145-154.

${ }^{12}$ Phillipps, 15, 78-80.

${ }^{13}$ James Belich, Replenishing the Earth: the Settler Revolution and the Rise of the Anglo World, 17831939 (Oxford: Oxford University Press, 2009), 41-42.

${ }^{14}$ Alison Drummond \& L R Drummond, At Home in New Zealand: An Illustrated History of Everyday Things Before 1865 (Auckland: Blackwood \& Janet Paul, 1967), 65-66; Anna Petersen, New Zealanders at Home: A Cultural History of Domestic Interiors, 1814-1914 (Dunedin: University of Otago Press, 2001), 17.

15“"A Williams Memorial, Two Great Brothers, Their Work for the Maori," Auckland Star, 19 March 1925,8 .

16“'Old Stories Retold, The Last Methodist Pioneer Missionary, Founding of Whaingaroa and Waikato Missions," New Zealand Herald, 20 July 1895, 1.

17,'Journal," New Zealand Spectator and Cook's Strait Guardian, 16 November 1850, 4; Alex Frame, Grey and Iwikau: A Journey into Custom (Wellington: Victoria University Press, 2003), 17-25.

18“In the Forties, Life in New Zealand, Stories Grave and Gay, Doctoring the Maoris," Evening Post, 14 July 1928, 17.

19" A Contrast,"New Zealand Herald, 17 June 1879, 6 (the barque Platina is incorrectly referred to as the Planter by the New Zealand Herald); Ani Pihema, "Te Kawau, Apihai - Te Kawau, Apihai," Dictionary of New Zealand Biography, Te Ara - the Encyclopedia of New Zealand, accessed 24 October 2013, http://www.TeAra.govt.nz/en/biographies/1t42/te-kawau-apihai

${ }^{20}$ Wood to Colonial Secretary, 5 April 1850, IA1 85, 1850/520, National Archives (NA), Wellington.

${ }^{21}$ Smith, "Report: Onehunga Station," to Inspector Captain Atkins, 4 February 1849, IA1 85, 1849/296, NA, Wellington. 
${ }^{22}$ Beckham to Colonial Secretary, 21 December 1848, IA1 85, 1848/2932, NA, Wellington.

${ }^{23}$ Daily Southern Cross, 14 October 1876, 5.

${ }^{24}$ Daily Southern Cross, 10 December 1862, 3.

${ }^{25}$ 'A Story of the Olden Time', New Zealand Herald, 23 June 1888, 1.

${ }^{26 ،}$ 'G.T.C.', 'Old Identities - No.20', Daily Southern Cross, 6 November 1875, 3.

${ }^{27}$ 'Church Jubilee', EP, 5 November 1830, 12.

28 'Harbour Master's Report on the Houses for Immigrants', 15 June 1842, ACGO 8333, Box 33, 1842/1088, NA, Wellington.

${ }^{29}$ R. C. J. Stone, From Tāmaki-makau-rau to Auckland (Auckland: Auckland University Press, 2001), 272.

${ }^{30}$ Mallcott to Superintendent of Public Works, 28 June 1842, ACGO 8333, Box 33, 1842/1149, NA, Wellington.

${ }^{31}$ Titipa to the Governor, undated letter, ACGO 8333, Box 33, 1842/55, NA, Wellington.

${ }^{32}$ Fitzroy to Sinclair, 17 May 1844, ACGO 8333, Box 33, 1844/109, NA, Wellington.

${ }^{33}$ Shaw, 15.

${ }^{34}$ Manawatu Standard, 31 December 1912, 5.

${ }^{35} 5$ Victoriae No.17, 'An ordinance for imposing a tax on raupo houses'.

36"'Tax on houses, early New Zealand," Rodney and Otamatea Times, Waitemata and Kaipara Gazette, 8 August 1923, 7.

${ }^{37}$ Hunter to Shortland, 22 November 1842, ACGO 8333, Box 26, 42/2064, NA, Wellington.

38,"Public Meeting,", New Zealand Gazette and Wellington Spectator, 2 April 1842, 3.

39 "A Working Man," "Original Correspondence," New Zealand Colonist and Port Nicholson Advertiser, 22 November 1842, 2.

40"'The Memorial of the Mayor and the Aldermen of the Borough of Wellington," 25 August 1843, ACGO 8333, Box 26, 43/1777; Richmond to Colonial Secretary, 11 September 1843, ACGO 8333, Box 26, 43/2019, NA, Wellington.

${ }^{41}$ New Zealand Gazette and Wellington Spectator, 27 September 1843, 2.

${ }^{42}$ Perry to Richmond, 2 October 1843, ACGO 8333, Box 26, 1843/219 [Enclosure], NA, Wellington.

${ }^{43}$ Richmond to Perry, 3 October 1843, ACGO 8333, Box 26, 1843/219 [Enclosure], NA, Wellington.

${ }^{44}$ Shepherd to Colonial Secretary, 14 November 1843, ACGO 8333, Box 26, 1843/2125, NA, Wellington.

45"How to build a house in the bush," Daily Southern Cross, 13 September 1869, 7.

46" Auckland," Press, 19 May 1864, 2.

47،"Terrible Conflagration at Tauranga," Colonist, 13 June 1865, 3.

${ }^{48}$ James Fentress and Chris Wickham, Social Memory: Perspectives on the Past (Oxford: Blackwell, 1992), 127.

${ }^{49}$ Fentress and Wickham, 88.

${ }^{50}$ Angela Wanhalla, In/Visible Sight: the Mixed-Descent Families of Southern New Zealand (Wellington: Bridget Williams Books, 2009), 107.

51 “'No. 6. Comparative table showing the numbers and descriptions of houses or buildings in New Zealand (exclusive of the Chatham Islands) in December 1858, and December 1861, respectively, with the increase or decrease shown by the census of 1861, and the proportion of the population to the houses at the respective periods," Statistics New Zealand, accessed 25 October 2013, http://www3.stats.govt.nz/historic_publications/1861-statistics-nz/1861-statistics-nz.html; "Table 7.1. Comparative table showing the numbers and descriptions of houses in New Zealand, in December 1861 and December 1864, respectively, with the increase or decrease shown by the census of 1864, and the proportion of the population to the houses at the respective periods," Statistics New Zealand, accessed 25 October 2013, http://www3.stats.govt.nz/historic_publications/1864-statistics-NZ/1864-statisticsNZ.html; "Table showing the numbers and descriptions of houses (inhabited), and the domestic condition of the population (exclusive of aboriginal native), in New Zealand, as ascertained by a census 
taken in December, 1867," Statistics New Zealand, accessed 25 October 2013, http://www3.stats.govt.nz/historic_publications/1867-statistics-nz/1867-statistics-nz.html.

52،"The Census," Daily Southern Cross, 14 January 1865, 4.

53"'Statistics," Wellington Independent, 22 May 1869, 4.

54"'The Census of 1858," Wellington Independent, 21 June 1859, 3.

55" Census of New Zealand," Nelson Examiner and New Zealand Chronicle, 12 July 1862, 2.

56"The Census," Lyttlelton Times, 16 July 1862, 4.

57"Statistics of the Colony," Nelson Examiner and New Zealand Chronicle, 11 March 1865, 2.

${ }^{58}$ Southland Times, 3 August 1868, 3.

${ }^{59}$ Miles Fairburn, The Ideal Society and its Enemies: the Foundation of Modern New Zealand Society 1850-1900 (Auckland: Auckland University Press, 1990), 19.

60“'Devonia," "Reminiscences of Taranaki Pioneers," Auckland Star, 3 November 1909, 6.

${ }^{61}$ New Zealand Herald, 31 March 1883, 1.

62“"An Early Settler," "Auckland Twenty Years Ago," Daily Southern Cross, 10 December 1862, 3.

${ }^{63}$ Dugald MacFarlane, "The First House on the Plains," Letter to the Editor, Star, 27 September 1900, 1.

64،"Testimony to Old Taranakians," Hawera \& Normanby Star, 3 January 1924, 4.

${ }^{65}$ Zamiel, Te Aroha News, reprinted from the Auckland Star, 17 April 1889, 6.

${ }^{66}$ Gordon MacDonald, "The Hermit of Milford Sound," Otago Daily Times, 11 January 1906, 10.

67"Special Auckland Representative," "Hung Grimly to Hut, Old Man Became Threatening and Looked Dangerous, Sent to Mental Hospital," NZ Truth, 25 July 1829, 9.

${ }^{68}$ Petersen, 40.

69،"Illness at Parihaka," Taranaki Herald, 23 October 1884, p.2; T W Lewis,"The health of the natives," Taranaki Herald, 19 January 1885, 2.

70““Common Skin Infections: Cellulitis, Erysipelas, Impetigo," Physicians'Desk Reference, accessed 28 October 2013,

http://www.pdrhealth.com/diseases/common-skin-infections-cellulitis-erysipelas-impetigo

${ }^{71}$ 'The Maori Race," Press, 17 June 1905, 4; Kristyn Harman, "Protecting Tasmanian Aborigines:

American and Queensland Influences on the Cape Barren Island Reserve Act 1912," Journal of Imperial and Commonwealth History, 41, 5 (2013): 744-764.

${ }^{72}$ Raeburn Lange, May the People Live: A History of Maori Health Development 1900-1920 (Auckland: Auckland University Press, 1999), 147-153.

73،"Maori Race: Past and Present Effects of Civilisation, Contact with Pakeha," Evening Post, 23 May $1935,22$.

${ }^{74}$ Vincent O'Malley, The Meeting Place: Māori and Pākehā Encounters, 1642-1840 (Auckland: Auckland University Press, 2012); Rebecca Burke, "Friendly relations between the two races were soon established"? Pākehä interactions with Māori in the planned settlements of Wellington, Nelson and New Plymouth, 1840-1860 (PhD thesis, Victoria University of Wellington, 2013). 